\title{
The Progress and Achievement of Top Five Services Sectors through the Foreign Direct Investments in India
}

\author{
K. Pagavathi, K. Prabhakar Rajkumar
}

\begin{abstract}
Foreign Direct Investment (FDI) plays a very important role in the development of the nation. It is very much vital in the case of underdeveloped and developing countries. A typical characteristic of these developing and underdeveloped economies is the fact that these economies do not have the needed level of savings and income in order to meet the required level of investment needed to sustain the growth of the economy. In such cases, foreign direct investment plays an important role in bridging the gap between the available resources or funds and the required resources or funds. It plays an important role in the long-term development of a country not only as a source of capital, but also for enhancing competitiveness of the domestic economy through transfer of technology, strengthening infrastructure, raising productivity and generating new employment opportunities. In India, FDI is considered as a developmental tool, which helps in achieving self-reliance in various sectors and in the overall development of the economy. India after liberalizing and globalizing the economy to the outside world in 1991, there was a massive increase in the flow of foreign direct investment. The present paper attempts to analyze the significance of the FDI Inflows in Indian service sector since 1991 and relating the growth of service sector FDI in the generation of employment in terms of skilled and unskilled. The services sector is not only the dominant sector in India's GDP, but has also attracted significant foreign investment flows, contributed significantly to exports as well as provided large-scale employment. India's services sector covers a wide variety of activities such as trade, hotel and restaurants, transport, storage and communication, financing, insurance, real estate, business services, community, social and personal services, and services associated with construction.
\end{abstract}

Keywords : Foreign Direct Investment, Indian Service Sector, Make in India, Gross Domestic Product Growth.

\section{INTRODUCTION}

Foreign direct investment (FDI) has played an important role in the process of globalization during the past two decades. The rapid expansion in FDI by multinational enterprises since the mid-eighties may be attributed to significant changes in technologies, greater liberalization of trade and investment regimes, and deregulation and privatization of markets in many countries including developing countries like India. Capital formation is an important determinant of economic

Revised Manuscript Received on September 25, 2019

K. Pagavathi, Ph.D. Research Scholar, Department of Commerce, Periyar University, Salem, Tamil Nadu

Dr. K. Prabhakar Rajkumar, Associate Professor, Department of Commerce, Periyar University, Salem, Tamil Nadu growth. While domestic investments add to the capital stock in an economy, FDI plays a complementary role in the overall capital formation and in filling the gap between domestic savings and investment. At the macro-level, FDI is a non-debt-creating source of additional external finances. At the micro-level, FDI is expected to boost output, technology, skill levels, employment and linkages with other sectors and regions of the host economy. In India FDI inflow made its entry during the year 1991-92 with the aim to bring together the intended investment and the actual savings of the country. To pursue a growth of around 7 percent in the Gross Domestic Product of India, the net capital flows should increase by at least 28 to 30 percent on the whole. But the savings of the country stood only at 24 percent.

The gap formed between intended investment and the actual savings of the country was lifted up by portfolio investments by Foreign Institutional Investors, loans by foreign banks and other places, and foreign direct investments. Among these three forms of financial assistance, India prefers as well as possessing the maximum amount of Foreign Direct Investments. Hence FDI is considered as a developmental tool for growth and development of the country. Therefore, this study is undertaken to analyze the flow of FDI into the country identifying the various sets of factors which determine the flow of FDI.

The services sector is not only the dominant sector in India's GDP, but has also attracted significant foreign investment flows, contributed significantly to exports as well as provided large-scale employment. India's services sector covers a wide variety of activities such as trade, hotel and restaurants, transport, storage and communication, financing, insurance, real estate, business services, community, social and personal services, and services associated with construction.

\section{REVIEW OF STUDIES ON FDI IN INDIA}

The following studies would highlight the nature and dimension of FDI inflows into India at different periods, and more particularly after the post-economic reform periods. One study measured the trend of FDI in India from 1970 to 2007 using time series analysis

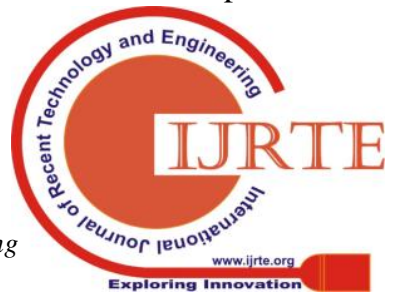


and identified the causes of variationsand another study brought out that even India and China had the better economic condition, China getting inflow more FDI than IndiaThe study identified in what way FDI was important for economic development of India in respect of increased domestic investment, human capital and technology. And the impact was increased job creation in manufacturing industries, healthcare projects, education and research. A study evaluated the relationship of domestic investment size, FDI flow and economic growth from 1992 to 2012 in India. The Granger Causality test was applied and it was found that GDP and domestic investments had mutual relationship, but FDI did not have an interrelation with domestic investments. And also, there was no direct connectivity between FDI and economic growth in India. FDI is a significant avenue for technology transfer into a developing economy like India and made foreign collaborations with sectoral contribution, as well state wise growth. In India during the post-economic reform period the FDI inflow increased significantly after the initiation of economic reforms. FDI is a significant contributor to GDP of Indian economy and FDI inflow was much higher after the post-economic liberalization period. During 1990-2012, FDI had a significant impact on export and GDP in India. And the period from 2000 to 2010, the electrical equipment industry attracted the highest FDI with $15.6 \%$ of total FDI. During 1991-2013, there was a strong link between FDI and GDP in India.

\section{OBJECTIVES OF THE STUDY}

The review studies on FDI showed its contribution to Indian economy. However, there is a need for further investigation to find out the pattern of investment and the priorities of investing countries on sectoral investment. Such analysis would give an insight into learning the new emerging pattern and sectoral contribution, empirically in Indian economy. In this context, it is pertinent to take up such a broad-based study to examine the linkage between FDI inflow and sectorial growth, as well forecasting future FDI scenario in India. Therefore, the present study is set to examine the following specific objectives:

1. To examine the performance of FDI on sectoral investment.

2. To analyses the growth trends of various sectors in India.

3. To investigate the impact of FDI on selected macro-economic variables.

\section{HYPOTHESIS}

The study proposes the following hypothesis to achieve the objectives:

1. There is a positive growth trend of FDI inflows into India.

2. There is a significant impact of FDI on GDP, Total Trade (TT) and Foreign Exchange Reserves (FER) of India

\section{METHODOLOGY AND DATA ANALYSIS}

This research is a descriptive study in nature. The secondary data was collected from various journals, magazines, and websites, particularly from the Department of Industrial Policy \& Promotion, Ministry of Commerce and Industry, Government Websites, Reports and publications, Industry, Agencies, Historical documents and other sources of published information, Secretariat of Industrial Assistance (SIA), Central Statistical Organization (CSO).

\section{STATUS OF FDI IN INDIA}

As reported by UBS security of India, the country doubled FDI inflows over the past decade, accounting for 1.9 $\%$ of GDP in 2016-17. It is further expected, the inflows are likely to rise to $2.5 \%$ of GDP over the next five years. Unlike China, Indian Government has phased out FDI policies that will be increasingly recognized as a favored destination by overseas investors. A notable feature of FDI inflows is that the manufacturing sector has been picking up fast as compared to other sectors. The report indicates that in 2016-17, the largest increase in FDI was in the telecom sector, followed by insurance. Apart from that, the country attracted higher investments in cement, electrical equipment, banking services, metallurgical industries, and broadcasting in recent years.

The performance of FDI in India: Sectorial Analysis

The FDI had entered into several sectors after initiation of Liberalization and Privatization of Indian economy by the central government to drive economic growth on the path of economic recovery. In this context, the performance of top ten sectors of the economy as well top ten destinations of FDI inflows in 2018, are discussed. The results are presented in Table 1.

It is evident from the table that FDI inflows showed an encouraging investment in the top five sectors like service $(17.61 \%)$, computer hardware and software $(8.27 \%)$, Telecommunication $(8.15 \%)$, construction development $(6.38 \%)$ and trading $(5.18 \%)$ of total inflows in the country during 2018. Likewise, the highest shares of investing countries are Mauritius (33.13\%), Singapore $(18.81 \%)$, Japan $(7.23 \%)$, The UK $(6.70 \%)$, Netherlands $(6.24 \%)$ and The USA $(6.24 \%)$ respectively. The contributions from other countries were insignificant of total inflows.

Of total FDI inflows, $51.94 \%$ accounted for Mauritius and Singapore; whereas industrialized countries such as the UK, The USA, Japan, France and German contributed together to the extent of $24.21 \%$; and the others were $3.97 \%$.

The sector-wise analysis reveals that the share of the top three sectors such as service, computer and telecommunication put together accounted for $34.03 \%$ of total inflows in 2018 . These sectors are largely attracted by the investors due to viability and long-term profitability. The other sectors, such as automobiles, trading and power will also have a greater potential for making investment by the investors during the period under study.

Table 1: Countries-wise and sectors-wise FDI inflows in India in 2018

\begin{tabular}{|l|l|l|l|l|}
\hline Rank & $\begin{array}{l}\text { Name of } \\
\text { Country }\end{array}$ & $\begin{array}{l}\text { Total } \\
\text { Inflows } \\
(\%)\end{array}$ & $\begin{array}{l}\text { Name of } \\
\text { Sector }\end{array}$ & $\begin{array}{l}\text { Total } \\
\text { Inflows } \\
(\%)\end{array}$ \\
\hline
\end{tabular}




\begin{tabular}{|c|c|c|c|c|}
\hline 1 & Mauritius & 33.13 & $\begin{array}{l}\text { Service } \\
\text { Sector }\end{array}$ & 17.61 \\
\hline 2 & Singapore & 18.81 & $\begin{array}{l}\text { Computer } \\
\text { Hardware } \\
\text { and } \\
\text { Software }\end{array}$ & 8.27 \\
\hline 3 & Japan & 7.23 & $\begin{array}{l}\text { Telecom } \\
\text { municatio } \\
\mathrm{n}\end{array}$ & 8.15 \\
\hline 4 & $\begin{array}{l}\text { United } \\
\text { Kingdom }\end{array}$ & 6.70 & $\begin{array}{l}\text { Constructi } \\
\text { on } \\
\text { Developm } \\
\text { ent }\end{array}$ & 6.38 \\
\hline 5 & Netherlands & 6.24 & Trading & 5.18 \\
\hline 6 & U.S.A & 5.84 & $\begin{array}{l}\text { Automobi } \\
\text { le } \\
\text { Industry }\end{array}$ & 4.95 \\
\hline 7 & Germany & 2.82 & $\begin{array}{l}\text { Drugs \& } \\
\text { Pharmace } \\
\text { uticals }\end{array}$ & 4.06 \\
\hline 8 & Cyprus & 2.47 & Chemicals & 3.95 \\
\hline 9 & France & 1.62 & Power & 3.64 \\
\hline 10 & UAE & 1.50 & $\begin{array}{l}\text { Constructi } \\
\text { on }\end{array}$ & 3.36 \\
\hline
\end{tabular}

Source: SIA Newsletters

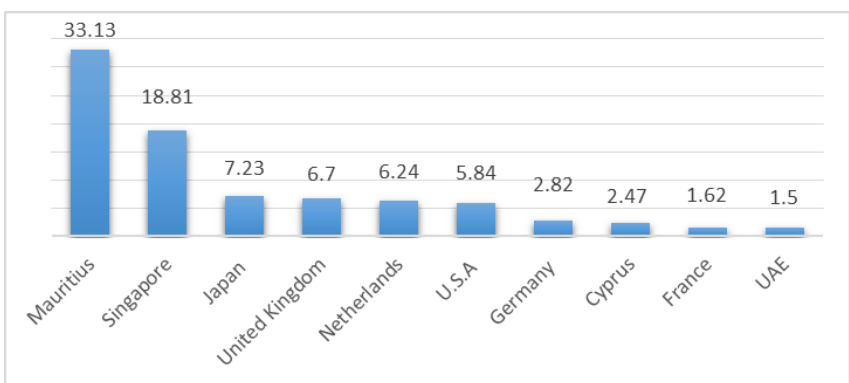

Figure 1: Country wise FDI inflows India.

According to Department of Industrial Policy and Promotion (DIPP), Government of India, the total FDI investment in India during April-June, 2018 stood at US\$ 12.75 billion. The achievement of higher investment is perhaps due to Government's effort to improve the ease of doing business and relaxation in FDI norms with the investing countries. For the same period, the service sector received the highest FDI equity inflow of US\$ 2.43 billion; followed by Trading (US\$ 1.63 billion), Telecommunication (US\$ 1.59 billion) and computer software and Hardware (US\$ 1.41 billion). The country-wise inflows during the period indicates that the maximum FDI equity inflows received from Singapore (US\$ 6.52 billion); followed by Mauritius (US\$ 1.49 billion), Japan (US\$ 0.87 billion), Netherlands US\$ 0.84 billion), and United Kingdom (US\$.0.65 billion) respectively.

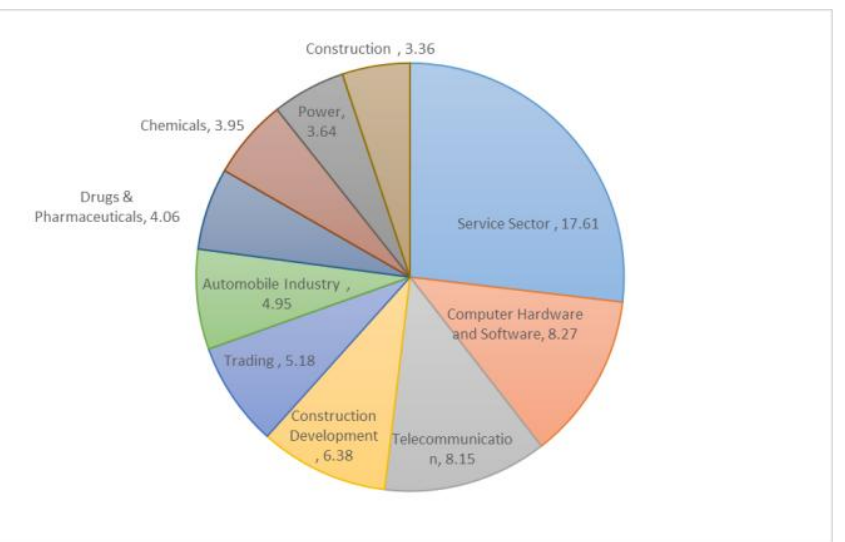

Figure 2: Sector wise FDI inflows in India

\section{Service Sector in India}

Today, in India service sector accounts more than 50 percent of India's Gross Domestic Product (GDP). There is a significant change in the sectoral contribution of each sector to India's GDP over a period of time. In 1950-51 the primary sector was contributing about 56.5 percent to the Indian GDP. It is followed by the secondary sector with 13.6 percent and tertiary sector with 29.9 percent. During 1990-91 the share of agriculture sector in India GDP was 34 percent. It was followed by the secondary sector with 23.2 percent and tertiary sector with 42.8 percent. During 2007 the contribution of primary sector came down to 18 percent, and industrial sector increased to 29 percent sector to 53 percent (Misra and Puri, 2009). During 2008-09 the share of the primary sector was 15.7 percent, the share of the secondary sector was 28 percent and the share of the service sector was 56.4 percent (GOI, 2010) which highlights the fact that the share of tertiary sector is rising constantly over a period of time.

\section{Banking sectors in India}

As per the Reserve Bank of India (RBI), India's banking sector is sufficiently capitalized and well-regulated. The financial and economic conditions in the country are far superior to any other country in the world. Credit, market and liquidity risk studies suggest that Indian banks are generally resilient and have withstood the global downturn well. The Indian banking industry has recently witnessed the rollout of innovative banking models like payments and small finance banks. RBI's new measures may go a long way in helping the restructuring of the domestic banking industry. The digital payment system in India has evolved the most among 25 countries with India's Immediate Payment Service (IMPS) being the only system at level 5 in the Faster Payments Innovation Index (FPII). 


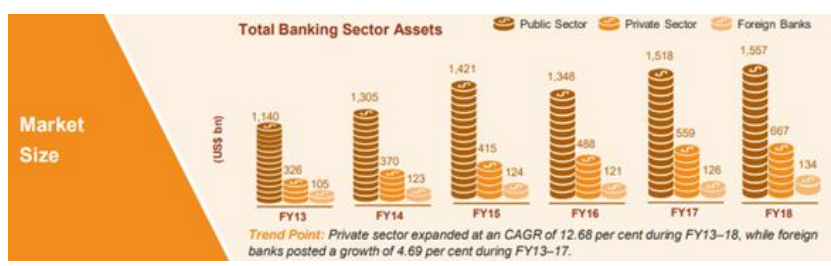

Figure 3: Market size of Banking Sectors

\section{Advantages in India}

Robust Demand: increase in working populations and growing disposable income will raise the demand of banking and related services. Rural banking is also expected to increase in the future. Innovation in Services: Mobile banking, internet banking and various extensions of the facilities at the ATM stations will improve the operational efficiency. Business Fundamentals: Healthy business fundamentals can be reflected through high interest margins. Policy Support: The industry has health regulatory oversight along with credible monetary policy by the Reserve Bank of India (RBI).

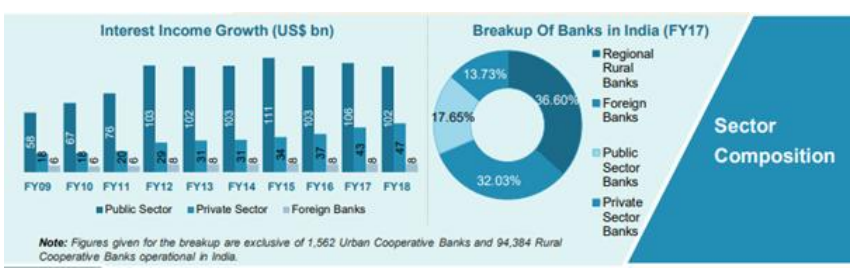

Figure 4: Sector Composition of Banking Sectors

\section{Nationalized Bank in India}

\begin{tabular}{|c|c|}
\hline & $\begin{array}{l}\text { HDFC Bank Limited is a } \\
\text { holding company. The bank } \\
\text { offers a range of banking } \\
\text { services covering commercial } \\
\text { and investment banking on } \\
\text { the wholesale side and } \\
\text { transactional/branch banking on } \\
\text { the retail side. It also offers } \\
\text { financial services. The bank's } \\
\text { segments include treasury, } \\
\text { retail banking, wholesale } \\
\text { banking and other banking } \\
\text { business. }\end{array}$ \\
\hline & $\begin{array}{l}\text { ICICI Bank Limited is a } \\
\text { banking sector company. The } \\
\text { bank is engaged in providing } \\
\text { a range of banking and } \\
\text { financial services, including } \\
\text { commercial banking, retail } \\
\text { banking, project and corporate } \\
\text { finance, working capital } \\
\text { finance, insurance, venture } \\
\text { capital and private equity, } \\
\text { investment banking, broking } \\
\text { and treasury products and } \\
\text { services. }\end{array}$ \\
\hline
\end{tabular}

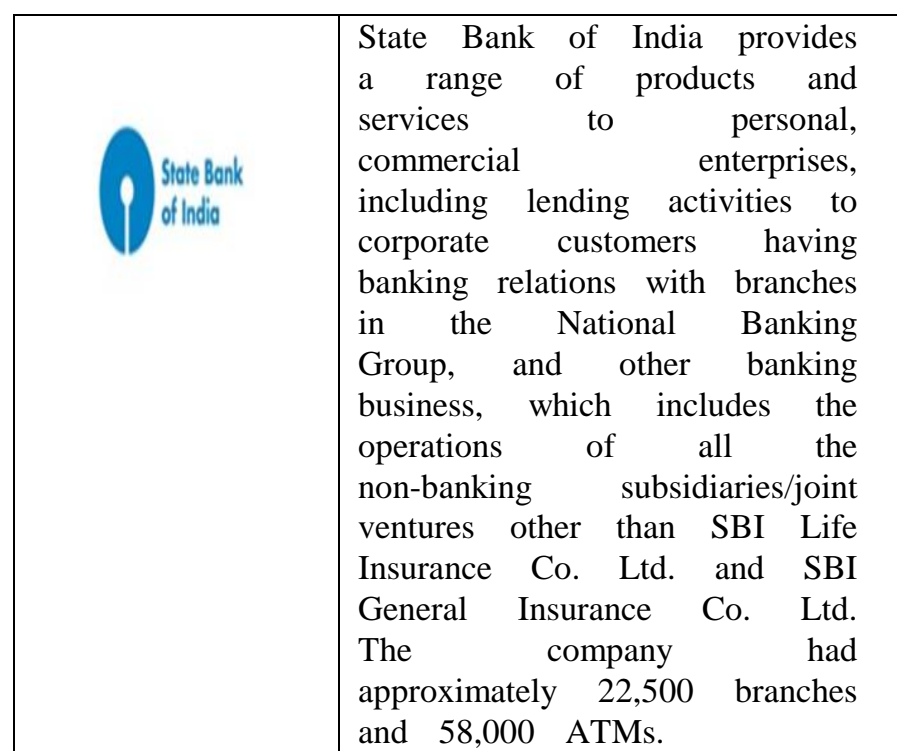

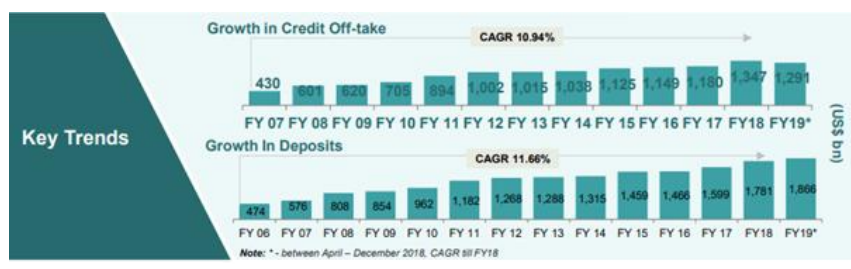

Figure 5:Key Trends of Banking Sectors

Financial services in India

India has a diversified financial sector undergoing rapid expansion, both in terms of strong growth of existing financial services firms and new entities entering the market. The sector comprises commercial banks, insurance companies, non-banking financial companies, co-operatives, pension funds, mutual funds and other smaller financial entities. The banking regulator has allowed new entities such as payments, banks to be created recently thereby adding to the types of entities operating in the sector. However, the financial sector in India is predominantly a banking sector with commercial banks accounting for more than 64 per cent of the total assets held by the financial system. The Government of India has introduced several reforms to liberalize, regulate and enhance this industry. The Government and Reserve Bank of India (RBI) have taken various measures to facilitate easy access to finance for Micro, Small and Medium Enterprises (MSMEs). These measures include launching Credit Guarantee Fund Scheme for Micro and Small Enterprises, issuing guideline to banks regarding collateral requirements and setting up a Micro Units Development and Refinance Agency (MUDRA). 


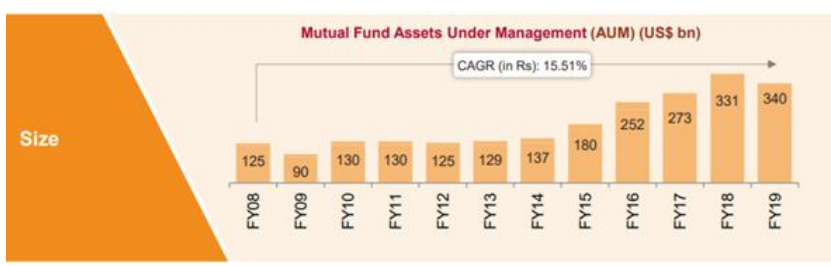

Figure 6: Market size of Financial Sectors

\section{Advantage India:}

Growing Demand: Rising incomes are driving the demand for financial services across income brackets. Innovation: India benefits from a large cross- utilization of channels to expand reach of financial services. Policy Support: government has approved new banking licenses and increased the FDI limit in the insurance sector. Growing penetration: Credit, insurance and investment penetration are rising in rural areas. Moreover, the wealth management segment has witnessed growing HNWI participation.

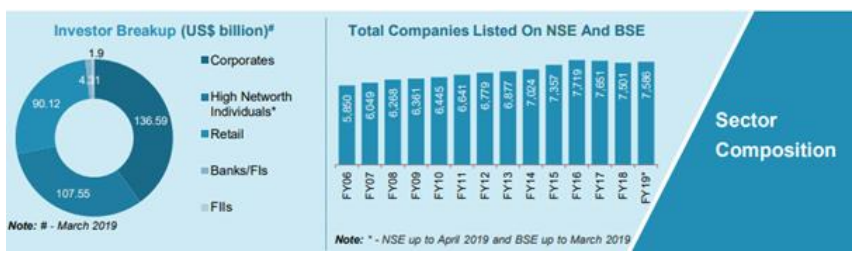

Figure 7: Sector Composition of Financial Sectors

\begin{tabular}{|c|c|}
\hline & $\begin{array}{l}\text { Muthoot Finance limited is a } \\
\text { gold financing company. The } \\
\text { company is a non-banking } \\
\text { financial company (NBFC), which } \\
\text { is engaged in providing loan } \\
\text { (financing) against collateral of } \\
\text { gold jewelry. The company } \\
\text { operates through two segments: } \\
\text { financing and power generation. } \\
\text { The company provides personal } \\
\text { and business loans (secured by } \\
\text { gold jewelry) primarily to } \\
\text { individuals having no access to } \\
\text { formal credit for a reasonable } \\
\text { tenure to meet their short-term } \\
\text { working capital requirements. }\end{array}$ \\
\hline & $\begin{array}{l}\text { Bajaj Finserv Limited is a } \\
\text { holding company for various } \\
\text { financial services businesses. The } \\
\text { company is engaged in the } \\
\text { business of promoting financial } \\
\text { services, such as finance, } \\
\text { insurance and wealth management, } \\
\text { through its investments in } \\
\text { subsidiaries and joint ventures. } \\
\text { The company is also engaged in } \\
\text { the business of generating power } \\
\text { through wind turbines, a } \\
\text { renewable source of energy. }\end{array}$ \\
\hline
\end{tabular}

\begin{tabular}{|l|l|}
\hline IICICIPRDENTILY Prudential Life Insurance \\
Company Limited is a life insurance \\
company, which is a joint venture \\
between ICICI Bank Limited and \\
Prudential Corporation Holdings \\
Limited. The company provides life \\
insurance, pensions and health insurance \\
to individuals and groups. It conducts \\
business in participating, \\
non-participating and unit linked lines of \\
businesses.
\end{tabular}

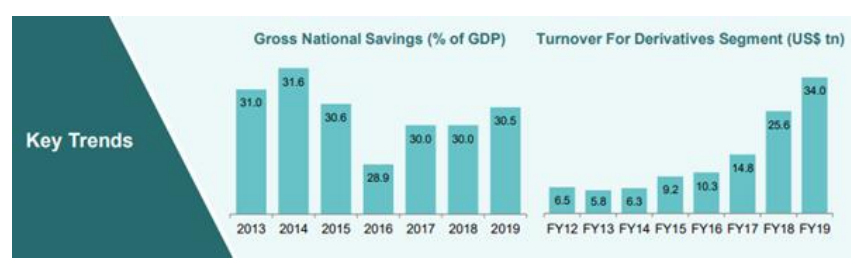

Figure 8: Key Trends of Financial Sectors

\section{Indian Insurance industry Overview \& Market Development Analysis}

The insurance industry of India consists of 57 insurance companies of which 24 are in life insurance business and 33 are non-life insurers. Among the life insurers, Life Insurance Corporation (LIC) is the sole public sector company. Apart from that, among the non-life insurers there are six public sector insurers. In addition to these, there is sole national re-insurer, namely, General Insurance Corporation of India (GIC Re). Other stakeholders in Indian Insurance market include agents (individual and corporate), brokers, surveyors and third-party administrators servicing health insurance claims.

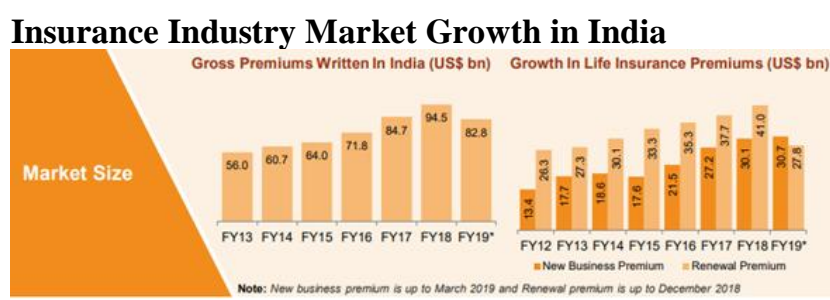

Figure 9: Market size of Insurance Sectors

\section{Advantage India:}

Robust Demand: Insurance industry in India is expected to reach US\$ 280 billion by 2020, driven by increasing awareness, innovative products and more distributions channels. Attractive opportunities: insurance reach is still low in India. overall insurance penetration (premiums as \%of GDP) in India was 3.69 per cent in 2017 , providing a huge underserved market. Policy support: full flexibility given to insurance Regulatory and development Authority (IRDAI) under the insurance bill to frame regulations for the sector. Increasing investments: insurance sector companies in India raised around Rs 434.3 billion (US\$ 6.7 billion) through public issues in 2017 . 


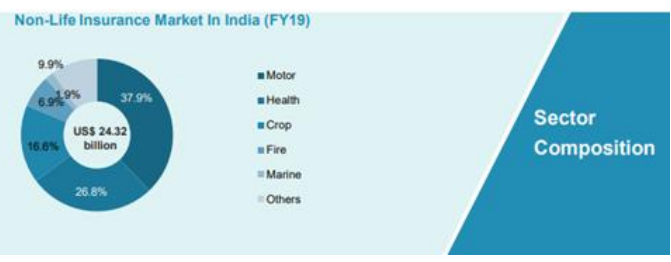

Figure 10: Sector Composition of Insurance Sectors

\section{Insurance Companies in India}

\begin{tabular}{|l|l|}
\hline Insurance Companies in India \\
Currently a leading private \\
general insurer in India, ICICI \\
Lombard was started in 2001 as \\
a joint venture between ICICI \\
Bank and Fairfax Financial \\
Holdings. Over the years, it has \\
grown rapidly along with India's \\
insurance industry. In FY19, it \\
became the fourth largest \\
non-life insurance company in \\
the country and issued 26.5 \\
million new policies. Its Gross \\
Direct Premium Income (GDPI) \\
has grown as a CAGR of 13.9 \\
per cent between FY08-18 to \\
reach Rs 123.57 billion (US\$ \\
1.92 billion).
\end{tabular}

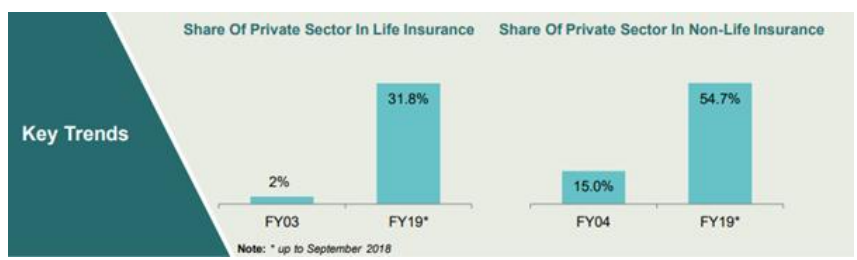

Figure 11: Key Trends of Insurance Sectors

\section{Services Sectors in India}

The services sector is not only the dominant sector in India's GDP, but has also attracted significant foreign investment flows, contributed significantly to exports as well as provided large-scale employment. India's services sector covers a wide variety of activities such as trade, hotel and restaurants, transport, storage and communication, financing, insurance, real estate, business services, community, social and personal services, and services associated with construction.

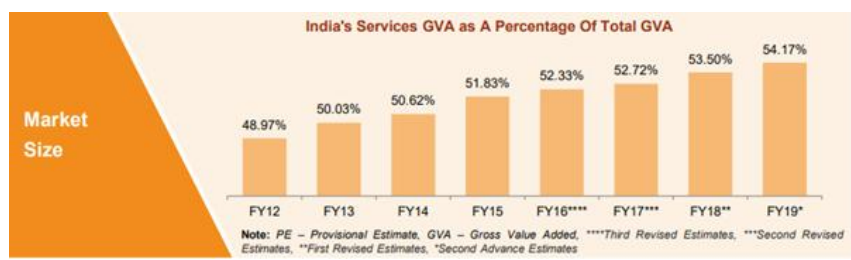

Figure: 12 Market size of Services Sectors

\section{Advantage India:}

Robust Demand: India is the export hub for software services. It has a 55 percent share in the US\$ 185-190 billion global sourcing market in 2017. It is also becoming a destination for medical tourism as a result of cheaper but quality health care services. Competitive Advantage: large pool of skilled manpower, especially in the areas of IT\&ITeS available at a relatively low cost and a rapidly increasing youth population looking to migrate from agriculture to other sectors. Policy support: Government of India is working to remove many trade barriers to services and tabled a draft legal text on trade facilitation in services to the WTO in 2017. Increasing investments: services sector is the largest recipient of FDI in India with inflows of US\$70.91 billion between April 2000 and December 2018

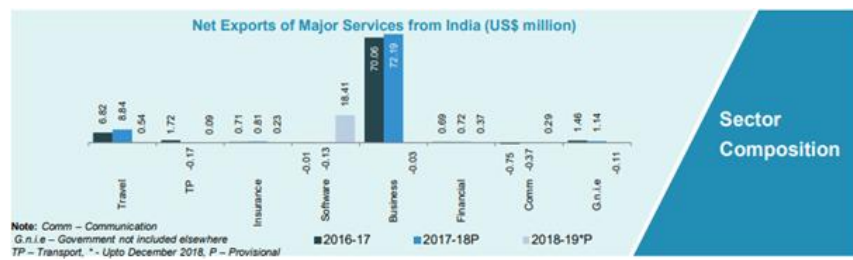

Figure 13: Sector Composition of Services Sectors

\section{List of Top Services Companies in India}




\begin{tabular}{|l|l|}
\hline HDFC Bank Limited (the Bank) is a \\
holding company. The bank offers a \\
range of banking services covering \\
commercial and investment \\
banking on the wholesale side and \\
transactional/branch banking on the \\
retail side. It also offers financial \\
services. The bank's segments \\
include treasury, retail banking, \\
wholesale banking and other \\
banking business.
\end{tabular}

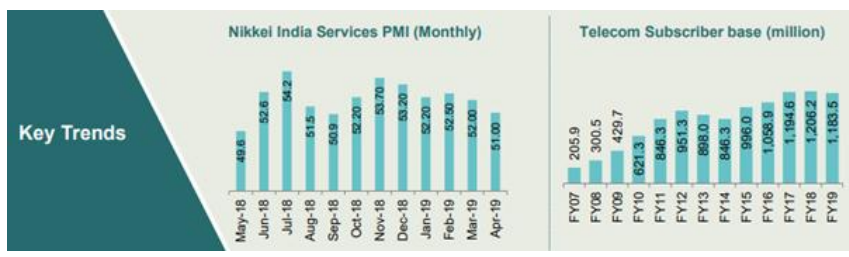

Figure 14:Key Trends of Services Sectors

\section{Road Ahead}

Services sector growth is governed by both domestic and global factors. The sector is expected to perform well in FY16. The Indian facilities management market is expected to grow at a 17 percent CAGR between 2015 and 2020 and surpass the $\$ 19$ billion mark supported by booming real estate, retail, and hospitality sectors. The performance of trade, hotels, and restaurants, transport, storage and communication sectors are expected to improve in FY17. Loss of growth momentum in commodity-producing sectors had adversely impacted transport and storage sectors over the past two years. The financial, insurance, real estate and business services sectors are also expected to continue their good run in FY17. The growth performance of the community, social and personal services sector is directly linked with government expenditure and we believe that the government will remain committed to fiscal consolidation in FY16.

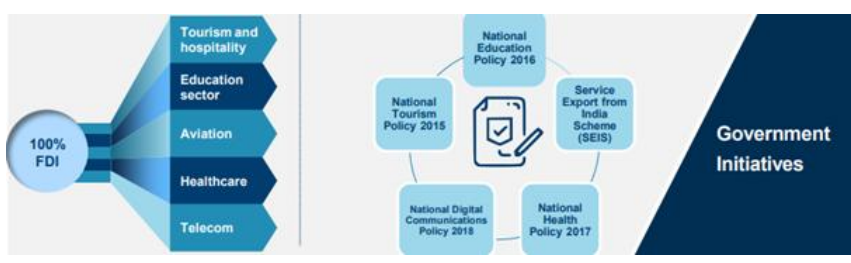

Figure 15 Government Initiatives of Service Sectors

\section{CONCLUSION}

FDI plays an important role in the long-term development of a country not only as a source of capital, but also for enhancing the competitiveness of the domestic economy through the transfer of technology, strengthening infrastructure, raising productivity and generating new employment opportunities. India emerges as the fifth largest recipient of foreign direct investment across the globe and second largest among all other developing countries (World Investment Report 2010). The huge market size, availability of highly skilled human resources, sound economic policy, abundant and diversified natural resources all these factors enable India to attract FDI. Further, it was found that even though there has been increased flow of FDI into the country during the post liberalization period, the global share of FDI in India is very less when it is compared to other developing countries. Lack of proper infrastructure, unstable government, and political environment, high corporate tax rates and limited export processing zones are considered to be the major problems for low FDI into the country. To overcome this situation, the Government should revise the sectoral cap and bring more sectors under the automatic route. Further, India should sign the agreement of Double Taxation treaties with other countries in order to increase bilateral trade. Therefore, there is an urgent need to adopt innovative policies and good corporate governance practices on par with international standards, by the Government of India, to attract more and more foreign capital in various sectors of the economy to make India a developed economy.

\section{REFERENCES}

[1] BalasundaramManiam and

Amitiava Chatterjee. "The Determinants of US Foreign Investments in India: 
Implications and Policy Issues," Managerial Finance, Vol. 24, No. 7, 1998, pp. 55-62.

[2] Nagesh Kumar, "Liberalization and changing patterns of FDI. Has India's relative Attractiveness as a host of FDI improved?" Economic Developments in India, 2001, pp. 79-99

[3] Balasubramanyam.V.N. and Vidya Mahambre "Foreign Direct Investment in India," Working Paper No.2003/001, Department of Economics, Lancaster University Management School, International Business Research Group, 2003.

[4] Birendra Kumar Nayak and Surya Dev. "Low Bargaining Power of Labour Attracts ForeignDirect Investment in India", Social Science Research Network, No.431060, 2003.

[5] Laura Alfaro, "Foreign Direct Investment and Growth: Does the Sector Matter?", Working Paper Harvard Business School, April 2003.

[6] Sebastin Morris. "A Study of the Regional Determinants of Foreign Direct Investment inIndia, and the case of Gujarat," Working Paper No. 2004/03/07, 2004, Indian Institute of Management.

[7] Rajih Kumar Sahoo, "Foreign Direct Investment and Growth of Manufacturing Sector: An Empirical Study on Post Reforms India", is a doctoral thesis submitted to the University of Mysore, 2005 